\title{
PERILAKU TUNA FUNGSI AUDITOR: PENGUJIAN ATAS KARAKTERISTIK PERSONAL DAN PENILAI KINERJA AUDITOR
}

\author{
Aprina Nugrahesthy \\ Fakultas Ekonomika dan Bisnis, Universitas Kristen Satya Wacana Salatiga \\ esthy@staff.uksw.edu
}

\begin{abstract}
Auditor dysfunctional behavior has been increasingly perceived to be prevalent in the audit environment. It is therefore interesting to study the association between auditors' personal characteristics, non-personal characteristics and dysfunctional behavior. This research investigates the relationship between locus of control as a specific personal characteristic, employees' personal performance, organizational commitment, turnover intention, auditors' performance assessors as a factor outside personal characteristics and acceptance of dysfunctional audit behavior. We collected data by sending questionnaire to auditors in Semarang and Surakarta cities based on the convenience sampling method because we had no precise information on the number of existing auditors beforehand. Using Structural Equation Model (SEM) to analyze our data, we find that there is no association between personal characteristic and the acceptance of dysfunctional audit behavior. Meanwhile, there is a significant relationship between auditors' performance assessor on the acceptance of dysfunctional audit behavior.
\end{abstract}

Keywords: personal characteristics, auditors' performance assessor, dysfunctional audit behavior.

\begin{abstract}
ABSTRAK
Fenomena perilaku tuna fungsi yang dilakukan oleh auditor makin dianggap lazim di lingkup audit. Hubungan antara karakteristik personal, karakteristik non personal dan perilaku tuna fungsi menjadi sesuatu hal yang menarik untuk diteliti. Penelitian ini menguji hubungan antara karakteristik personal berupa locus of control, tingkat kinerja pribadi karyawan, komitmen organisasi dan turnover intention dan penilai kinerja auditor sebagai faktor diluar karakteristik personal terhadap penerimaan perilaku tuna fungsi dalam lingkup audit. Pengumpulan data dilakukan melalui kuisioner dari responden yaitu auditor di KAP Kota Semarang dan Surakarta dengan metode convenience sampling karena populasi auditor yang bekerja tidak diketahui dengan pasti. Analisis data dengan menggunakan Model Persamaan Struktural. Hasil dari pengujian hipotesis mengindikasikan bahwa tidak ada hubungan antara karakteristik personal dengan penerimaan perilaku tuna fungsi dalam ruang lingkup audit. Sementara itu di lain sisi terdapat hubungan antara penilai kinerja auditor dengan penerimaan perilaku tuna fungsi dalam ruang lingkup audit.
\end{abstract}

Kata kunci: karakteristik personal, subjek penilai kinerja, perilaku tuna fungsi auditor. 


\section{PENDAHULUAN}

Riset terdahulu menemukan bahwa perilaku tuna fungsi (dysfunctional behavior) bagi perusahaan audit berpotensi merusak profesi auditor (Buchheit et al., 2003; Kelley \& Margheim 1990; Rhode 1978; Sweeney et al., 2010). Perilaku tuna fungsi merupakan bagian dari keputusan etis yang bisa disebabkan karena tekanan ketaatan (Lord \& DeZoort 2001; Cahyaningrum \& Utami 2015). Sementara itu, penelitian sebelumnya tentang pengambilan keputusan etis dari perilaku profesional konsultan pajak mengidentifikasi faktor-faktor seperti pertimbangan deontologi dan teleology (Burns \& Kiecker 1995), sensitivitas etis (Yetmar \& Eastman 2000) serta kesetaraan moral dan contractualism sebagai faktor-faktor personal yang dapat mempengaruhi penilaian etis terhadap perilaku profesional konsultan pajak. Penelitian lain menunjukkan bahwa budaya etis lingkungan juga berperan penting pada perilaku profesional konsultan pajak (Marshall et al., 1998;Bobek \& Radtke, 2007;Bobek et al., 2010). Pinsker et al., (2009) membuktikan bahwa peran akuntan mempengaruhi perilaku dan keputusan mereka terhadap pelaksanaan audit.

Dalam konteks audit,(Donnelly, Quirin, \& O’Bryan 2003) menemukan bahwa auditor berperilaku tuna fungsi yang didukung karena adanya karakteristik personal auditor berupa locus of control, turnover intention, tingkat kinerja pribadi karyawan, dan komitmen organisasi. Selain faktor internal, faktor dari luar yaitu penilai kinerja auditor juga berpotensi mempengaruhi perilaku auditor. Melalui mekanisme penilaian kinerja akan dapat diketahui bagaimana tugas dan tanggung jawab dari seorang karyawan dilaksanakan dan seberapa jauh hasilnya dalam memenuhi standar yang telah ditentukan (Januari et al., 2015). Salah satu faktor yang mempengaruhi proses penilaian kinerja adalah penilai kinerja. Penetapan penilai sangat erat hubungannya dengan persoalan apakah hasil penilaian objektif atau tidak (Hasibuan 2005). Penilaian yang kurang objektif akan berdampak pada perilaku auditor. Riset ini memperluas Donnelly et al. (2003) dengan memasukkan penilai kinerja auditor sebagai faktor eksternal yang akan mempengaruhi perilaku tuna fungsi, selain faktor internal yaitu locus of control, turnover intention, tingkat kinerja pribadi karyawan, dan komitmen organisasi.

Penelitian Hwang dan Chang (2010) menemukan bahwa lingkungan audit dan tekanan klien cenderung akan mempengaruhi keputusan auditor dalam menerima pelaporan keuangan yang agresif atau manipulatif, dengan kata lain tekanan oleh klien menyebabkan auditor melakukan penyimpangan terhadap prosedur dan aturan audit. Penelitian terkait perilaku tuna fungsi auditor di Indonesia telah dilakukan oleh Maulina et al. (2010) menemukan bahwa 92 persen dari 57 auditor setuju untuk melakukan premature sign-off.

Fenomena perilaku tuna fungsi auditor di Indonesia cukup mengkhawatirkan. Hal ini ditunjukkan dengan fakta bahwa Departemen Keuangan sebagai pengawas Akuntan Publik dan Kantor Akuntan Publik hampir setiap tahun mengeluarkan Surat 
Keputusan Pembekuan Ijin Akuntan Publik. KAP Drs. Tahir Hidayat dan Dody Hapsoro dibekukan dengan Keputusan Menteri Keuangan Nomor 397/KM.1/2008 dikarenakan yang bersangkutan telah melakukan pelanggaran terhadap Standar Auditing - Standar Profesional Akuntan Publik dalam pelaksanaan audit atas laporan keuangan konsolidasdi PT Pupuk Sriwidjaya (Persero) dan anak perusahaannya. KAP Mitra Winata dan Rekan juga dibekukan ijin operasionalnya selama dua tahun terhitung sejak 15 Maret 2007 sesuai dengan Keputusan Menteri Keuangan Nomor 423/KM.6/2002 dikarenakan ada pelanggaran terhadap Standar Profesional Akuntan Publik yang berkaitan dengan pelaksanaan audit atas Laporan Keuangan PT Muzatek Jaya. Selain itu Drs. Petrus Mitra Winata selaku akuntan publik dari KAP Mitra Winata dan Rekan juga telah melakukan pelanggaran atas pembatasan penugasan audit umum dengan melakukan audit umum atas laporan keuangan PT. Muzatek Jaya, PT. Luhur Artha Kencana dan Apartemen Nuansa Hijau sejak tahun 2001 sampai dengan 2004. Pembekuan ijin Akuntan Publik dilakukan kepada Yahya Santosa selama satu tahun sesuai dengan Keputusan Menteri Keuangan Nomor 92/KM.1/2008 dikarenakan yang bersangkutan telah melakukan pelanggaran terhadap Standar Auditing - Standar Profesional Akuntan Publik berupa pembatasan penugasan audit umum atas Laporan Keuangan PT. Pusako Tarinka, Tbk mulai tahun buku 2003 - 2006. Kasus-kasus di atas merupakan bukti nyata bahwa perilaku tuna fungsi auditor benar-benar ada dan terjadi.

Donelly et al. (2003) memberi bukti empiris karakteristik personal sebagai indikator diterimanya perilaku tuna fungsi auditor, dengan hasil seorang auditor dengan locus of control eksternal cenderung lebih menerima perilaku tuna fungsi, seorang auditor dengan keinginan untuk berpindah kerja yang tinggi cenderung lebih menerima perilaku tuna fungsi, sebaliknya seorang auditor dengan komitmen organisasi yang tinggi cenderung tidak menerima perilaku tuna fungsi, sementara tingkat kinerja karyawan tidak berhubungan dengan penerimaan perilaku tuna fungsi auditor. Sweeney et al. (2009) menguji dampak budaya etis dari Kantor Akuntan Publik dari niat untuk terlibat dalam perilaku tuna fungsi. Bobek, Hageman, dan Radtke (2015) menyelidiki sejauh mana peran profesional dan jenis kelamin dalam mempengaruhi pengambilan keputusan etis profesional auditor termasuk di dalamnya menerima atau menolak perilaku tuna fungsi. Penelitian ini menduga bahwa karakteristik personal memiliki hubungan dengan penerimaan perilaku tuna fungsi auditor.

Pekerjaan di bidang apapun pada akhirnya akan melalui proses penilaian kinerja atau evaluasi, yaitu proses untuk mengidentifikasi dan mengukur sifat, perilaku, serta pencapaian karyawan secara individual atau berkelompok sebagai dasar untuk membuat keputusan atau perencanaan pengembangan oleh supervisor, manajer, ataupun rekan sekerja (Cummings \& Worley 2005). Penggunaan sistem penilaian kinerja antara lain adalah dapat membuat keputusan yang lebih baik, kepuasan dan motivasi karyawan yang lebih tinggi, komitmen yang lebih kuat 
terhadap perusahaan, sehingga perusahaan bisa menjadi lebih efektif Steensma dan Visser (2007). Sistem penilaian kinerja terkadang dapat berjalan tidak lancar, salah satu sebabnya adalah tidak adanya rasa memiliki karena karyawan tidak dilibatkan dalam proses sehingga mereka tidak terlatih, serta perbedaan kredibilitas atasan sebagai penilai (Grote 2002). Di sisi lain faktor subjektivitas seperti diskriminasi dalam lingkungan kerja, budaya, ras, jenis kelamin, struktur organisasi, stereotip umum, distorsi persepsi, dan perilaku sosial juga dapat mempengaruhi (Millmore et $a l .$, 2007). Sistem penilaian kinerja yang fair tentu akan lebih diterima baik oleh para karyawan dan itu berarti kecil kemungkinan diterimanya perilaku tuna fungsi, sehingga penelitian ini menambahkan penilai kinerja auditor sebagai faktor di luar karakteristik personal untuk membuktikan diterimanya perilaku tuna fungsi auditor.

Byrne (2011) menyatakan auditor dengan locus of control internal dianggap tingkat tekanan kerjanya terhadap pekerjaan lebih rendah, dan melaporkan tingkat kepuasan kerja dan kinerja yang lebih tinggi terhadap pekerjaannya. Chen et al. (2006) mengungkapkan bahwa dua faktor yang sangat berpengaruh pada turnover intention adalah kepuasan kerja dan komitmen organisasi. Kepuasan kerja merupakan aspek pertama dicapai sebelum seorang karyawan memiliki komitmen organisasi. Karyawan dengan komitmen organisasi yang tinggi memiliki perbedaan sikap dibandingkan yang berkomitmen rendah. Komitmen organisasi yang tinggi menghasilkan performa kerja, rendahnya tingkat absen, dan rendahnya tingkat keluar-masuk (turnover) karyawan. Karyawan yang berkomitmen tinggi akan memiliki produktivitas tinggi (Luthans 2011).

Hasil riset terdahulu terkait perilaku tuna fungsi sangat beragam dan lebih banyak memfokuskan pada faktor internal yaitu karakteristik personal auditor, sementara faktor lain yang berpotensi memiliki hubungan dengan penerimaan perilaku tuna fungsi adalah faktor eksternal yaitu penilai kinerja auditor. Penilai kinerja auditor menjadi faktor penting diluar karakteristik personal karena melalui penilaian kinerja yang objektif diharapkan dapat meminimalisasi perilaku tuna fungsi, selain itu belum ada riset yang mengemukakan secara detail mengenai mekanisme penilaian kinerja di lingkup audit sehingga menjadi menarik untuk dijadikan salah satu faktor eksternal terkait perilaku tuna fungsi auditor. Riset ini bertujuan untuk menguji beberapa variabel terkait karakteristik personal terhadap perilaku individu, khususnya terkait perilaku tuna fungsi auditor sekaligus menguji apakah terdapat hubungan di luar karakteristik personal berupa penilai kinerja auditor yang berkaitan dengan perilaku tuna fungsi auditor.

Penelitian ini diharapkan memberikan kontribusi dalam pengembangan ilmu, terutama dalam bidang akuntansi keperilakuan dan auditing serta dapat dipakai sebagai acuan untuk penelitian-penelitian mendatang. Selain itu penelitian ini diharapkan dapat memberikan kontribusi praktis yaitu bagi para profesi auditor untuk dapat merencanakan praktik manajemen sehingga mendorong pekerjaan audit yang berkualitas. 


\section{KAJIAN PUSTAKA DAN PERUMUSAN HIPOTESIS}

\section{Theory Planned Behavior (TPB)}

Teori pendukung dari penerimaan perilaku tuna fungsi auditor adalah Theory of Planned Behavior (TPB) yang dikembangkan oleh Ajzen pada tahun 1988 dan 1991 dengan intensi perilaku seseorang (behavioral intention) dipengaruhi oleh sikap yang mengarah pada perilaku (attitude toward the behavior), norma subjektif (subjective norm), dan pengendalian perilaku persepsian (perceived behavioral control).

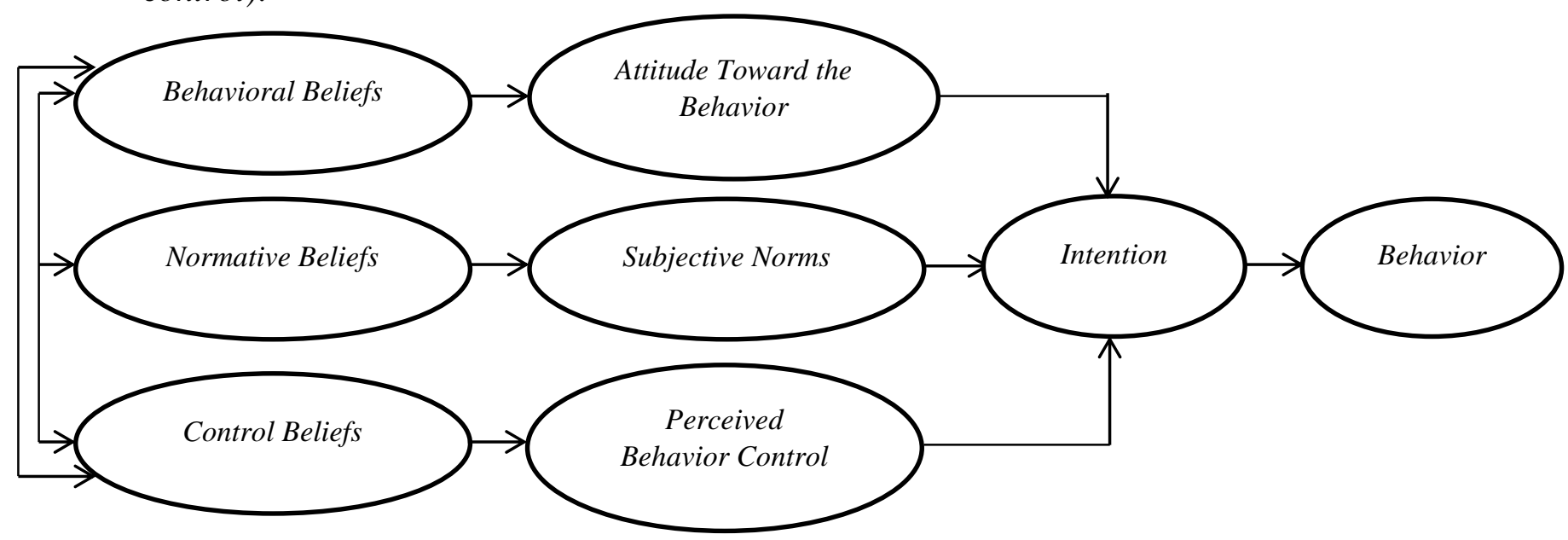

Gambar 1

Kerangka Theory of Planned Behavior (TPB)

Keyakinan atas perilaku (behavioral beliefs), keyakinan normatif (normative beliefs) dan keyakinan pengendalian (control beliefs) masing-masing memiliki korelasi hubungan yang pada akhirnya berpengaruh pada terbentuknya sikap yang mengarauh pada perilaku (attitude toward the behavior), norma subjektif (subjective norm) dan pengendalian perilaku persepsian (perceived behavioral control). Ketiga hal tersebut yang membentuk intensi dan berpengaruh pula pada perilaku seseorang. Sikap yang mengarah pada perilaku berhubungan dengan locus of control yaitu ketika keberhasilan seseorang ditentukan dari faktor internal atau eksternal. Keyakinan inilah yang akhirnya mendorong seseorang berperilaku menerima atau menolak perilaku tuna fungsi auditor. Kaitan dengan norma subjektif adalah ketika auditor menerima perilaku tuna fungsi auditor maka persepsi tekanan sosial yang akan muncul adalah adanya pelanggaran prinsip serta kode etik akuntan publik yang memang dibuat untuk membatasi sikap dan perilaku auditor dalam pelaksanaan tugasnya agar profesionalitasnya selalu terjaga. Pengendalian perilaku persepsian muncul ketika perilaku seseorang bukan lagi dikendalikan oleh diri sendiri dan juga oleh norma yang berlaku, namun juga oleh faktor lain di luar itu. Penilai kinerja auditor adalah faktor eksternal di luar kendali individu yaitu teman sekerja auditor, 
baik partner, manajer, supervisor, maupun staf yang dinilai memiliki hubungan dengan penerimaan perilaku tuna fungsi auditor.

\section{Perilaku Tuna Fungsi Auditor}

Donnelly et al. (2003) menyebutkan bahwa dysfunctional audit behavior merupakan suatu bentuk reaksi terhadap lingkungan atau semisal sistem pengendalian. Sistem pengendalian yang berlebihan akan menyebabkan terjadinya konflik dan mengarah pada perilaku tuna fungsi. Perilaku tuna fungsi audit dapat mengakibatkan penurunan kualitas audit baik secara langsung maupun tidak langsung. Sikap auditor yang menerima perilaku tuna fungsi merupakan indikator perilaku tuna fungsi aktual. Paino et al. (2011) menyatakan bahwa perilaku tuna fungsi dapat mempengaruhi kemampuan Kantor Akuntan Publik dalam memperoleh pendapatan, memenuhi kualitas kerja profesional, dan mengevaluasi kinerja pegawai dengan akurat, bahkan dalam jangka panjang dapat merusak kualitas audit.

Soobaroyen dan Chengabroyan (2006) menyatakan bahwa secara umum terdapat beberapa perilaku auditor yang diakibatkan oleh tekanan, yaitu memanipulasi pencatatan waktu, menilai bukti dan dokumen klien secara dangkal, melakukan penghentian langkah audit secara dini dan melaporkan chargable time yang tidak sebenarnya. Perilaku tuna fungsi audit dapat berupa premature sign off, underreporting of audit time dan altering and replacing of audit procedure. Premature sign off menurut Otley dan Pierce (1996) adalah tindakan yang dilakukan oleh auditor ketika melaksanakan program audit dengan cara menghentikan langkah audit tanpa menggantikannya dengan langkah yang lain. Penelitian oleh Otley dan Pierce (1996) menunjukkan bahwa salah satu bentuk penyimpangan perilaku yang mengurangi kualitas audit berupa underreporting of audit time atau melaporkan waktu audit dengan total waktu yang lebih pendek daripada waktu yang sebenarnya. Altering and replacing audit procedure terkait dengan penggantian prosedur audit. Lebih lanjut menurut Anastasia dan Mukhlasin (2005) altering and replacing of audit procedure adalah tindakan merubah dan atau mengganti prosedur audit yang telah ditetapkan dalam pelaksanaan audit di lapangan.

\section{Karakteristik Personal}

Karakteristik personal merupakan faktor-faktor yang secara unik berhubungan dengan individual atau ciri yang membedakan seseorang dengan orang lain (Gibson et al., 1995; Robbins 2000; Kreitner \& Kinicki 2001). Ford dan Richardson (1994) menjelaskan bahwa karakteristik personal meliputi kepribadian, gender, kebangsaan dan hasil-hasil dari proses sosialisasi dan pengembangan sumber daya manusia seperti komitmen organisasional serta komitmen profesional.

Seseorang dengan orang lain dapat dibedakan dengan menggunakan variabel kepribadian berupa locus of control yang mencerminkan tingkat keyakinan seseorang tentang sejauh mana perilaku yang diperbuat mempengaruhi keberhasilan atau kegagalan yang dialami. Individu dengan locus of control internal akan lebih 
mungkin berperilaku etis dalam situasi konflik audit dibandingkan individu dengan locus of control eksternal (Muawanah dan Indriantoro 2001). Turnover intention berkaitan dengan keinginan karyawan untuk berpindah pekerjaan. Penelitian terdahulu menemukan bahwa seseorang dengan turnover intention yang tinggi lebih dapat terlibat dalam perilaku tuna fungsi. Komitmen organisasi perlu dikembangkan selama proses sosialisasi ke dalam profesi yang dipilih dengan penekanan pada nilainilai profesi, karena masyarakat profesional memiliki karakteristik berbeda dalam memanfaatkan suatu organisasi (Utami et al., 2007). Seseorang yang memiliki komitmen serta loyalitas yang tinggi terhadap sebuah organisasi dimana dia bekerja maka tingkat kinerjanyapun akan tinggi dan kecil kemungkinan dia terlibat dalam perilaku tuna fungsi auditor.

\section{Penilai Kinerja Auditor}

Penilai kinerja auditor adalah pihak yang melakukan evaluasi terhadap karyawan dapat dilakukan perorangan maupun secara tim. Penilaian kinerja pada umumnya dilakukan melalui sebuah mekanisme yang telah ditentukan oleh masingmasing organisasi. Mekanisme penilaian tersebut biasanya bisa dilakukan oleh semua level auditor, baik partner, manager, supervisor, senior dan atau junior staff, bahkan rekan satu tim dan termasuk diri sendiri. Penilai kinerja auditor dari semua level diharapkan bisa mengurangi subjektifitas dalam melakukan evaluasi kinerja auditor, di antaranya karena ada faktor kedekatan dan "like/dislike".

\section{Pengembangan Hipotesis}

\section{Hubungan antara Locus of Control Eksternal dengan Penerimaan Perilaku Tuna Fungsi Auditor}

Seorang auditor dengan locus of control internal memiliki kemampuan untuk menghadapi ancaman-ancaman yang timbul dari lingkungan (Brownell 1981; Robberts et al., 1997; Pasewark \& Strawser 1996) dan berusaha memecahkan permasalahan dengan keyakinan mereka yang tinggi. Sebaliknya seorang auditor dengan locus of control eksternal lebih mudah merasa terancam dan tidak berdaya serta strategi yang dipilih dalam menyelesaikan sebuah permasalahan cenderung bersifat reaktif (Ardiansah 2003). Penelitian sebelumnya (Harini et al., 2010; Sitanggang 2007; Maryanti 2005; dan Donnelly et al., 2003) menunjukkan bahwa locus of control eksternal berpengaruh positif terhadap penerimaan perilaku tuna fungsi auditor. Seseorang dengan locus of control eksternal lebih bertanggungjawab dengan pihak-pihak lain dan faktor-faktor situasional, akibatnya mereka cenderung terlibat dalam perilaku tidak etis (Jones \& Kavanagh 1996; Trevino \& Youngblood 1990). Manipulasi atau ketidakjujuran pada akhirnya akan menimbulkan perilaku tuna fungsi auditor, sehingga hal ini menghasilkan dugaan bahwa semakin tinggi locus of control eksternal individu, semakin besar tingkat penerimaan perilaku tuna fungsi dalam audit. Berdasarkan argumentasi dan hasil riset terdahulu, dapat dirumuskan hipotesis pertama sebagai berikut : 
H1: Semakin tinggi locus of control eksternal, semakin tinggi penerimaan perilaku tuna fungsi dalam ruang lingkup audit.

\section{Hubungan antara Tingkat Kinerja Pribadi Karyawan dengan Penerimaan Perilaku Tuna fungsi Auditor}

Gable dan Dangello (1994) menyatakan bahwa perilaku tuna fungsi terjadi pada situasi ketika individu merasa dirinya kurang mampu mencapai hasil yang diharapkan melalui usahanya sendiri. Auditor yang memiliki persepsi yang rendah terhadap tingkat kinerja mereka akan menunjukkan tingkat penerimaan perilaku tuna fungsi yang lebih tinggi. Arens (2006) menyebutkan bahwa perilaku karyawan merupakan perwujudan atau manifestasi dari karakteristik seorang individu dalam menyesuaikan diri dengan lingkungannya, sehingga perilaku ini merupakan salah satu aspek yang sangat penting bagi individu dalam meningkatkan kinerjanya, khususnya perilaku etis.

Hyatt dan Prawitt (2001) menemukan bukti bahwa locus of control internal diasosiasikan dengan peningkatan kinerja. Lingkungan pekerjaan audit memerlukan karakteristik profesional dan teknis maka locus of control internal memberikan kinerja yang lebih tinggi. Nouri dan Parker (1998) dalam Donnelly et al. (2003) menemukan komitmen pada organisasi berdampak secara positif pada kinerja, sementara tidak ditemukan bukti adanya hubungan antara kinerja auditor dengan perilaku tuna fungsi auditor. Berdasarkan hasil riset terdahulu dan argumentasi di atas, dapat disusun rumusan hipotesis kedua sebagai berikut :

H2: Dengan kondisi adanya locus of control dan komitmen organisasi, semakin tinggi tingkat kinerja pribadi karyawan, maka semakin rendah penerimaan perilaku tuna fungsi dalam ruang lingkup audit.

\section{Hubungan antara Turnover Intention dengan Penerimaan Perilaku Tuna Fungsi Auditor}

Karyawan yang mengalami ketidakpuasan lebih mt alungkin meninggalkan pekerjaannya dibandingkan karyawan yang puas (Rutner et al., 2008). Hal ini didukung dengan penelitian survei yang dilakukan Kalbers dan Cenker (2007) serta Pasewark dan Viator (2006) terhadap auditor yang bekerja di Kantor Akuntan Publik, dengan hasil bahwa semakin tinggi kepuasan kerja mengakibatkan semakin rendah keinginan untuk berpindah. Malone dan Roberts (1996) menyatakan bahwa auditor yang memiliki keinginan untuk meninggalkan perusahaan lebih dapat terlibat dalam perilaku tuna fungsi karena menurunnya rasa takut akan kemungkinan jatuhnya sanksi apabila perilaku tersebut terdeteksi. Auditor yang memiliki keinginan untuk berhenti atau berpindah bekerja dapat membuat seseorang menjadi kurang peduli terhadap apa yang dilakukan dalam organisasi tempat bekerja. Sikap ini dapat mengakibatkan kinerja yang buruk bagi karyawan tersebut sehingga dapat menyebabkan terjadinya penyimpangan perilaku. Dengan demikian, auditor yang memiliki keinginan yang tinggi untuk berhenti bekerja dari perusahaan akan lebih 
menerima perilaku tuna fungsi. Donnelly et al. (2003) menyatakan bahwa turnover paling rendah ditemukan pada karyawan yang berkinerja sangat bagus. Auditor yang memiliki kinerja yang tinggi akan dipromosikan, sementara bagi yang tidak mampu mencapai standar kerja minimum akhirnya akan dikeluarkan dari perusahaan. Locus of control eksternal dianggap memperlihatkan tingkat yang lebih tinggi dalam keinginan untuk berhenti bekerja atau mencari alternatif pekerjaan lain dan belum terwujud dalam bentuk perilaku nyata. Komitmen organisasi merupakan alat prediksi yang sangat baik untuk beberapa perilaku penting, di antaranya adalah perputaran karyawan, kesetiaan karyawan kepada nilai organisasi dan keinginan untuk melakukan pekerjaan ekstra (untuk melakukan pekerjaan melebihi apa yang seharusnya dikerjakan).

H3: Dengan kondisi adanya tingkat kinerja pribadi karyawan, locus of control dan komitmen organisasi, semakin tinggi turnover intention maka semakin tinggi penerimaan perilaku tuna fungsi dalam ruang lingkup audit.

\section{Hubungan antara Penilai Kinerja Auditor dengan Penerimaan Perilaku Tuna Fungsi Auditor}

Penilaian kinerja merupakan suatu sistem formal dan terstrukur yang mengukur, menilai, dan mempengaruhi sifat-sifat yang berkaitan dengan pekerjaan, perilaku dan hasil, termasuk tingkat ketidakhadiran. Fokusnya adalah untuk mengetahui seberapa produktif seorang karyawan dan apakah karyawan tersebut dapat berkinerja sama atau bahkan lebih efektif pada masa yang akan datang, sehingga karyawan, organisasi, dan masyarakat semuanya memperoleh manfaat (Schuler \& Jackson 1996). Menurut Dessler (2005) salah satu permasalahan yang terdapat dalam proses penilaian kinerja adalah efek halo yaitu masalah yang muncul ketika peringkat yang diberikan oleh penilai kepada bawahan atas satu sifat tertentu membuat bias peringkat orang itu atas satu sifat lainnya. Hal ini bisa terjadi karena penilai menyukai atau tidak menyukai sifat karyawan yang dinilainya. Semakin beragam level penilai kinerja dan mekanisme penilaian kinerja maka akan semakin obyektif penilaiannya dan diharapkan semakin kecil penerimaan perilaku tuna fungsinya. Sistem penilaian kinerja terkadang dapat berjalan tidak lancar, salah satunya karena tidak adanya rasa memiliki karena karyawan tidak dilibatkan dalam proses sehingga mereka tidak terlatih, serta perbedaan kredibilitas atasan sebagai penilai (Gabris \& Ihrke 2000; Grote 2002). Di sisi lain faktor subjektifitas seperti diskriminasi dalam lingkungan kerja, budaya, ras, jenis kelamin, struktur organisasi, stereotip umum, distorsi persepsi, dan perilaku sosial juga dapat mempengaruhi (Millmore, Biggs, \& Morse 2007)

H4: Semakin beragam penilai kinerja auditor maka semakin rendah penerimaan perilaku tuna fungsi dalam lingkup audit. 


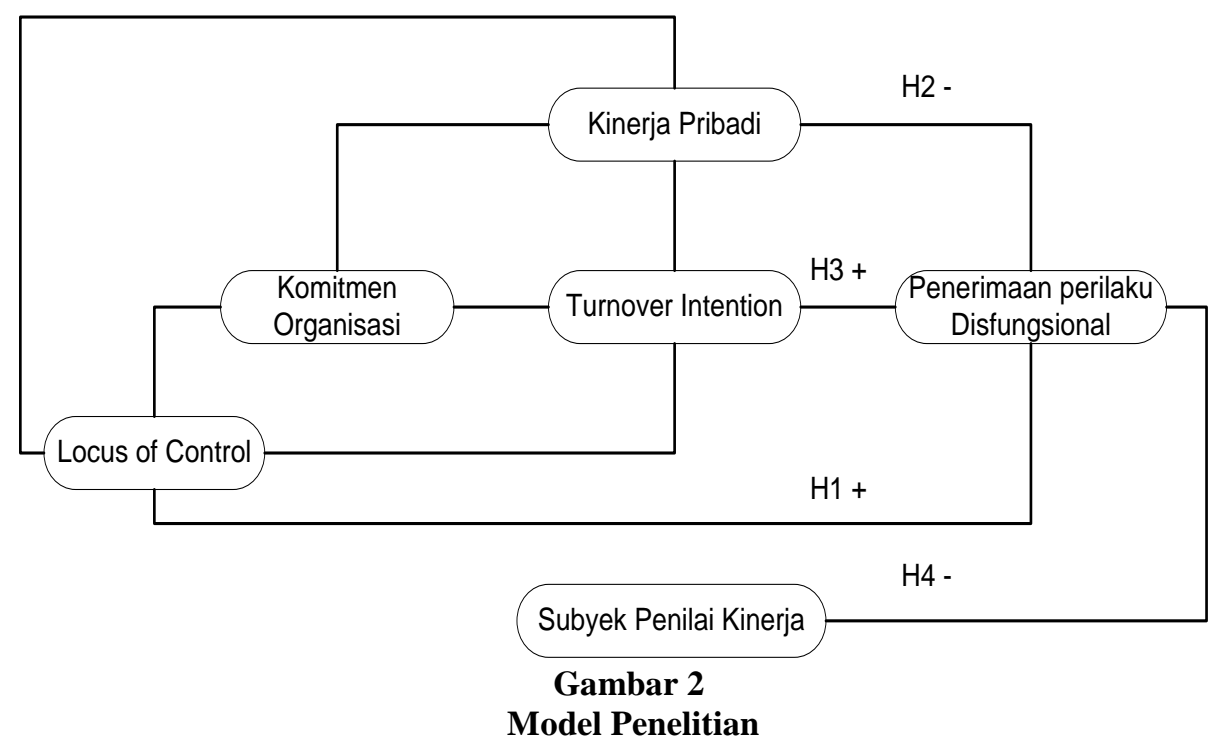

\section{METODA PENELITIAN}

Responden dalam penelitian ini adalah auditor yang bekerja di Kantor Akuntan Publik (KAP) di wilayah Kota Semarang dan Surakarta. Sampel dipilih dengan menggunakan metode convenience sampling karena jumlah auditor di tiap KAP tidak diketahui secara pasti. Pada penelitian ini terdapat 25 indikator, maka jumlah sampel minimum yang dibutuhkan adalah sebanyak 125. Data yang digunakan adalah data primer berupa data demografi responden, karakteristik personal, mekanisme penilaian kinerja, dan penerimaan perilaku tuna fungsi auditor. Teknik pengumpulan data dalam penelitian ini menggunakan survey berbantuan surat (mail survey).

Data demografi responden digunakan untuk menyajikan profil dari responden. Pengujian validitas dan reliabilitas dalam penelitian ini dilakukan dengan menggunakan Corrected Item to Total Correlation dan Cronbach's Alpha. Sementara untuk melakukan pengukuran konstruk dan pengujian hubungan antar variabel menggunakan Structural Equation Model (SEM) dari paket software statistic LISREL 8.8 dengan pertimbangan bahwa SEM memiliki kemampuan untuk menggabungkan measurement model dengan structural model secara simultan dan efisien bila dibandingkan dengan teknik multivariat lainnya (Hair et al., 1998). Penggabungan dari pengujian model struktural dan pengukuran tersebut memungkinkan untuk menguji kesalahan pengukuran (measurement error) sebagai bagian yang tak terpisahkan dari SEM dan melakukan analisis faktor bersamaan dengan pengujian hipotesis. Proses SEM mencakup delapan langkah yang harus dilakukan, yaitu: (1) konseptualisasi model, (2) penyusunan diagram alur (path diagram construction), (3) spesifikasi model dan menggambarkan sifat dan jumlah parameter yang diestimasi, (4) identifikasi model, (5) estimasi parameter, (6) penilaian model fit, (7) modifikasi model dan (8) validasi silang. 


\section{ANALISIS DAN PEMBAHASAN}

\section{Deskripsi Responden}

Sejumlah 150 kuesioner dikirimkan kepada responden dan kembali sejumlah 132 kuesioner dengan total 129 kuesioner yang dapat diolah. Tabel 1 menyajikan statistik deskriptif dari responden.

Tabel 1

Demografi Responden

\begin{tabular}{|c|c|c|}
\hline & Frekuensi & Persentase \\
\hline \multicolumn{3}{|l|}{ Jenis Kelamin } \\
\hline Laki-laki & 94 & $73 \%$ \\
\hline Perempuan & 35 & $27 \%$ \\
\hline \multicolumn{3}{|l|}{ Umur Responden } \\
\hline 20 s.d 30 tahun & 77 & $60 \%$ \\
\hline 30 s.d 40 tahun & 23 & $18 \%$ \\
\hline$>40$ tahun & 29 & $22 \%$ \\
\hline \multicolumn{3}{|l|}{ Jenjang Pendidikan } \\
\hline D3 & 46 & $36 \%$ \\
\hline $\mathrm{S} 1$ & 70 & $54 \%$ \\
\hline $\mathrm{S} 2$ & 9 & $7 \%$ \\
\hline S3 & 4 & $3 \%$ \\
\hline \multicolumn{3}{|l|}{ Jurusan } \\
\hline Akuntansi & 93 & $72 \%$ \\
\hline Non Akuntansi & 36 & $28 \%$ \\
\hline \multicolumn{3}{|c|}{ Posisi terakhir dalam pekerjaan } \\
\hline Junior Staff & 55 & $43 \%$ \\
\hline Senior Staff & 61 & $47 \%$ \\
\hline Supervisor & 12 & $9 \%$ \\
\hline Manajer & 1 & $1 \%$ \\
\hline
\end{tabular}

Dari hasil demografi responden diperoleh hasil bahwa responden adalah sebagian besar staf yunior, memiliki jenis kelamin laki-laki, umur 20 - 30 tahun, jenjang pendidikan S1 Akuntansi dengan posisi terakhir dalam jabatan sebagai staf. Tabel 2 menyajikan statistik deskriptif tiap variabel yang meliputi rata-rata dan kecenderungan jawaban dari responden. 
Tabel 2

Statistik Deskriptif

\begin{tabular}{|c|c|c|c|c|c|}
\hline Variabel & $\begin{array}{l}\text { Cron. } \\
\text { Alpha }\end{array}$ & Mean & $\begin{array}{l}\text { Std. } \\
\text { Dev. }\end{array}$ & Min & $\operatorname{Max}$ \\
\hline Locus of Control & 0,861 & 75,90 & 14,215 & 40 & 119 \\
\hline $\begin{array}{l}\text { Komitmen Organisasi } \\
\text { Tingkat Kinerja Pribadi }\end{array}$ & 0,861 & 37,69 & 9,959 & 9 & 61 \\
\hline Karyawan & 0,889 & 28,16 & 9,222 & 7 & 48 \\
\hline Turnover Intention & 0,728 & 11,49 & 3,790 & 3 & 21 \\
\hline $\begin{array}{l}\text { Penilai Kinerja Auditor } \\
\text { Penerimaan } \quad \text { Perilaku }\end{array}$ & 0,911 & 26,23 & 8,075 & 6 & 41 \\
\hline Tuna fungsi & 0,901 & 60,08 & 14,960 & 14 & 92 \\
\hline
\end{tabular}

\section{Uji Validitas dan Reliabilitas}

Uji validitas menggunakan Corrected Item to Total Correlation yang bertujuan untuk menguji validitas data terkait variabel dalam kuisioner. Data dikatakan valid jika nilai koefisien corrected item - total correlation> 0,30. Uji reliabilitas dilakukan dengan menggunakan Cronbach's Alpha yang bertujuan untuk mengetahui konsistensi alat ukur agar dapat diandalkan dan tetap konsisten jika pengukuran tersebut diulang. Data dikatakan reliabel jika koefisien bernilai minimal 0,60 atau lebih.

Tabel 3

Validitas dan Reliabilitas

\begin{tabular}{lcc}
\hline \multicolumn{1}{c}{ Variabel } & Valid & Reliabel \\
\hline Locus of Control & Valid & Reliabel \\
Komitmen Organisasi & Valid & Reliabel \\
Tingkat Kinerja Pribadi Karyawan & Valid & Reliabel \\
Turnover Intention & Valid & Reliabel \\
Penilai Kinerja Auditor & Valid & Reliabel \\
Penerimaan Perilaku Tuna fungsi & Valid & Reliabel \\
\hline
\end{tabular}

\section{Pengujian Kecocokan Model (Goodness of Fit)}

Model yang digunakan dalam penelitian ini menggunakan metode estimasi Maximum Likelihood. Metode ini merupakan metode estimasi yang sering digunakan untuk analisis data dengan menggunakan metode SEM dengan program Lisrel 8.8. Metode ini digunakan untuk mengetahui apakah model pengukuran yang telah diuji dan dianalisis dapat menjelaskan model struktural. 
Tabel 4

Uji Kecocokan Model Keseluruhan

\begin{tabular}{|c|c|c|}
\hline Kriteria & $\begin{array}{c}\text { Hasil } \\
\text { Estimasi } \\
\text { Model }\end{array}$ & $\begin{array}{c}\text { Indikator } \\
\text { Tingkat } \\
\text { Kecocokan }\end{array}$ \\
\hline RMSEA & $0,00 *$ & $<0,05$ \\
\hline$N F I$ & 0,19 & $>0,90$ \\
\hline$N N F I$ & 0,55 & $>0,90$ \\
\hline$C F I$ & 0,57 & $>0,90$ \\
\hline$I F I$ & 0,62 & $>0,90$ \\
\hline$R F I$ & 0,15 & $>0,90$ \\
\hline$R M R$ & 0,079 & $<0,05$ \\
\hline $\begin{array}{l}G F I \quad \text { dan } \\
A G F I\end{array}$ & $A G F I=0,69$ & $\begin{array}{l}G F I \quad>0,90 \\
(\text { good fit }) ; \\
0,90<G F I \\
>0,80 \\
(\text { marginal fit) } \\
A G F I=0-1\end{array}$ \\
\hline
\end{tabular}

Ket : *signifikan

\section{Hasil Pengujian Hipotesis}

Gambar 3 menunjukkan nilai koefisien jalur persamaan model struktural, sehingga dapat dilihat hubungan antar variabel bahwa ada hubungan langsung antara locus of control, tingkat kinerja pribadi, turnover intention dengan penerimaan perilaku tuna fungsi auditor, serta hubungan tidak langsung antar karakteristik personal dan komitmen organisasi dengan penerimaan perilaku tuna fungsi auditor. Koefisien jalur menunjukkan ada atau tidaknya hubungan langsung maupun tidak langsung antara karakteristik personal dan penilai kinerja auditor dengan penerimaan perilaku tuna fungsi. Hubungan langsung dengan penerimaan perilaku tuna fungsi terlihat dari hipotesis yang terbentuk, di luar itu merupakan hubungan antar variabel karakteristik personal yang secara tidak langsung berhubungan dengan penerimaan perilaku tuna fungsi.

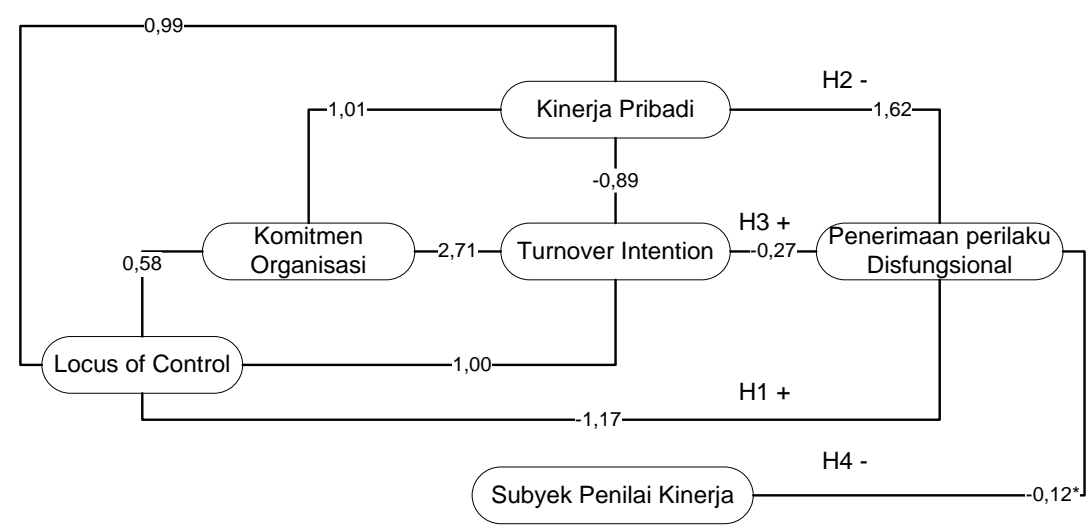

Gambar 3

Structural Equation Model dengan Koefisien Jalur 
Tabel 5 menunjukkan hubungan antar variabel dengan model persamaan struktural. Persamaan struktural dirumuskan untuk menyatakan hubungan kausalitas antar berbagai variabel.

Tabel 5

Model Persamaan Struktural

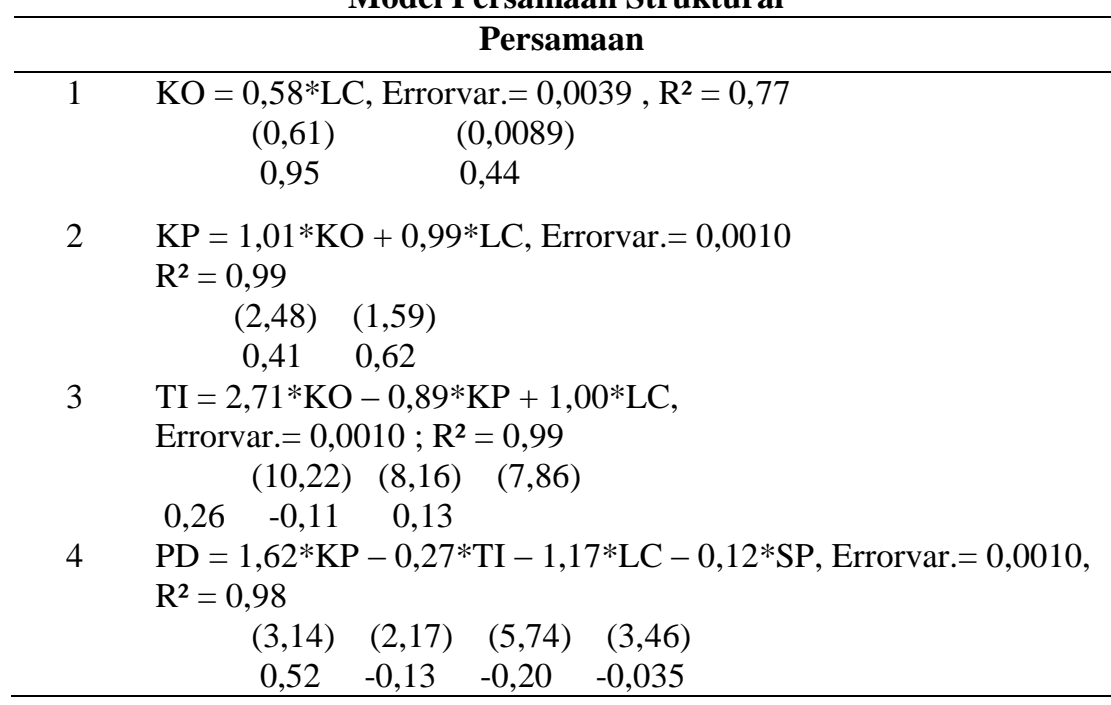

Hasil pengolahan data menunjukkan bahwa secara keseluruhan karakteristik personal (locus of control eksternal, tingkat kinerja pribadi karyawan, komitmen organisasi, dan turnover intention) tidak memiliki hubungan kausalitas dengan penerimaan tuna fungsi dalam ruang lingkup audit. Locus of control eksternal tidak berhubungan dengan dengan penerimaan perilaku tuna fungsi auditor. Hal ini berbeda dengan hasil penelitian Donnelly et al. (2003); Harini et al. (2010); Sitanggang (2007); Maryanti (2005) yang menunjukkan bahwa locus of control eksternal memiliki hubungan positif dengan penerimaan tuna fungsi auditor. Demikian pula hasil penelitian yang dilakukan oleh Trevino (1986); Trevino dan Youngblood (1990); Jones dan Kavanagh (1996) yang menyatakan bahwa seseorang yang memiliki locus of control eksternal cenderung terlibat dalam perilaku tidak etis, dan sebaliknya seseorang dengan locus of control internal cenderung untuk memilih tidak terlibat dalam perilaku etis. Perbedaan hasil penelitian ini dengan hasil penelitian terdahulu tersebut diduga karena sebagian besar auditor sebagai responden masih berada di level staf, sehingga dengan kesadarannya memiliki pemahaman bahwa keberhasilan yang diperolehnya tidak murni dari dirinya sendiri melainkan berasal dari pihak luar yaitu organisasi tempat bekerja beserta dengan orang-orang yang ada dalam pekerjaan tersebut (teman sekerja, pimpinan, dan klien). Jika pada kajian teori disebutkan bahwa seseorang dengan locus of control eksternal identik dengan manipulasi yang berujung pada penerimaan perilaku tuna fungsi (Brownell 1981; Robberts et al., 1997; Pasewark \& Strawser 1996), maka dugaan berikutnya berkaitan dengan hasil pengujian hipotesis ini adalah auditor memiliki keyakinan dan ketaatan penuh pada aturan yang mengikat kerja auditor serta konsekuensi jika aturan-aturan tersebut dilanggar. 
Tingkat kinerja pribadi karyawan tidak berhubungan dengan penerimaan perilaku tuna fungsi dalam ruang lingkup audit, dengan kondisi adanya locus of control dan komitmen organisasi. Hal ini sejalan dengan penelitian (Donnelly, Quirin, \& O'Bryan 2003) yang tidak menemukan bukti adanya hubungan antara kinerja auditor dengan perilaku tuna fungsi auditor. Di sisi lain penelitian Maryanti (2005) menyatakan bahwa kinerja memiliki hubungan positif dengan penerimaan perilaku menyimpang auditor karena auditor tidak menganggapnya sebagai perilaku tak etis melainkan sebagai cara untuk mendapatkan promosi. Solar dan Bruehl (1971) menyatakan bahwa individu yang melakukan pekerjaan di bawah standar yang ditetapkan lebih mungkin untuk melakukan tindakan penyimpangan sejak mereka melihat diri mereka sendiri tidak mampu untuk bertahan dalam pekerjaan melalui usaha mereka sendiri. Hasil penelitian yang menunjukkan tidak adanya hubungan antara tingkat kinerja karyawan dengan penerimaan perilaku tuna fungsi auditor diduga karena dilihat dari data demografi responden yang sebagian besar adalah staf yang berada pada level junior dan senior maka para auditor ini dengan kesadarannya melakukan yang terbaik untuk menunjukkan kinerjanya dengan terus berkomitmen pada organisasi tempat bekerja. Auditor merasa perlu mematuhi semua aturan kode etik dan standar profesi yang menjadi acuan utama dalam berperilaku, sehingga dalam kasus ini kemungkinan perilaku tuna fungsi dalam lingkup audit itu dapat terjadi adalah kecil.

Turnover intention tidak berhubungan dengan penerimaan perilaku tuna fungsi dalam ruang lingkup audit, dengan kondisi adanya tingkat kinerja pribadi karyawan, locus of control, dan komitmen organisasi. Hasil ini sesuai dengan penelitian Harini et al. (2010) yang menolak hubungan antara turnover intention dengan penerimaan perilaku tuna fungsi auditor dikarenakan auditor muda cenderung masih memiliki tingkat idealisme tinggi. Lain halnya dengan penelitian Maryanti (2005) dan Sitanggang (2007) yang membuktikan bahwa turnover intention memiliki pengaruh positif terhadap penerimaan perilaku tuna fungsi auditor. Hasil penelitian McEvoy dan Cascio (1987) juga menemukan turnover akan rendah diantara best performer. Malone dan Roberts (1996) menyatakan bahwa auditor yang memiliki keinginan berpindah kerja lebih mungkin terlibat dalam perilaku tuna fungsi karena adanya penurunan rasa takut dari kondisi yang mungkin terjadi bila perilaku tersebut terdeteksi. Lebih lanjut, individu yang berniat meninggalkan perusahaan dapat dianggap tidak begitu peduli dengan dampak buruk dari perilaku tuna fungsi terhadap penilaian kinerja. Hasil yang berbeda dari penelitian ini diduga juga disebabkan oleh sebagian besar responden yang berada di level staf, auditor ini sebagian besar sedang memulai merintis karir pekerjaannya sehingga belum berani untuk terlibat dalam perilaku tuna fungsi dalam lingkup audit.

Penilai kinerja auditor memiliki hubungan negatif dengan penerimaan tuna fungsi auditor. Hal ini menunjukkan bahwa para penilai kinerja telah menerapkan mekanisme penilaian kinerja dan telah dilakukan di seluruh Kantor Akuntan Publik 
wilayah Semarang dan Surakarta. Cascio (2006) menyebutkan bahwa penilaian kinerja mempunyai beberapa manfaat, yaitu untuk penerapan sistem reward dan punishment, memberikan umpan balik bagi karyawan untuk pengembangan karir, identifikasi kebutuhan pelatihan pengembangan bagi karyawan, dan mendiagnosa masalah dalam organisasi. Sementara itu, Mondy dan Noe (2005) menyatakan dalam kebanyakan organisasi, departemen sumber daya manusia bertanggung jawab untuk mengkoordinasikan desain dan pelaksanaan program penilaian kinerja, orang yang mungkin ditunjuk adalah atasan langsung, bawahan, peers, diri sendiri dan pelanggan. Demikian pula Mathis dan Jackson (2006) yang menyebutkan bahwa penilai kinerja merupakan siapapun yang mengetahui dengan baik kinerja dari karyawan secara individual, kemungkinannya yaitu supervisor, anak buah atau bawahan, anggota tim kerja, sumber-sumber dari luar, diri sendiri dan multisumber (umpan balik 360 derajat). Hal ini berarti ada objektifitas dalam penilaian kinerja berupa ragam penilai kinerja, sehingga sesuai dengan kajian teori yang menyatakan bahwa semakin beragam level penilai kinerja, maka penilaian kinerja akan jauh lebih objektif sehingga auditor tidak akan menerima perilaku tuna fungsi.

\section{SIMPULAN, KETERBATASAN DAN SARAN}

\section{Simpulan}

Penelitian ini menguji faktor-faktor yang berhubungan dengan keputusan untuk menerima perilaku tuna fungsi dalam ruang lingkup audit, yaitu dengan menguji secara simultan hubungan antara karakteristik individual auditor sebagai faktor internal berupa locus of control, komitmen organisasi, turnover intention dan tingkat kinerja pribadi karyawan serta penilai kinerja auditor terhadap penerimaan perilaku tuna fungsi dalam audit. Karakteristik personal auditor yang merupakan faktor internal meliputi locus of control, tingkat kinerja pribadi karyawan, turnover intention dan komitmen organisasi tidak memiliki hubungan dengan penerimaan perilaku tuna fungsi dalam ruang lingkup audit. Auditor menggunakan keyakinan dan kesadaran penuh dalam berperilaku dengan mempertimbangkan norma-norma subjektif yang membatasi dan mengikat tiap fungsi audit yang dilakukan oleh auditor, sehingga pelaksanaan audit dilaksanakan sesuai dengan tanggung jawab dan kesadaran auditor akan semua risiko yang dihadapi.

Penilai kinerja auditor memiliki hubungan negatif dengan penerimaan perilaku tuna fungsi dalam ruang lingkup audit, itu berarti bahwa di dalam KAP sudah terdapat mekanisme penilaian kinerja. Di samping itu auditor merasa bahwa penilai kinerja auditor turut menentukan evaluasi atas pekerjaan mereka, ketika penilaian tidak secara rutin dilakukan atau jika penilai kinerja auditor hanya pada level setara maka dimungkinkan akan terjadi penerimaan perilaku tuna fungsi dalam ruang lingkup audit. Sehingga dapat dilihat bahwa variabel ini justru lebih menjadi 
pertimbangan para auditor dalam melakukan penerimaan perilaku tuna fungsi atau tidak.

Responden dari penelitian ini didominasi oleh auditor pada level junior dan atau senior staf, sehingga tidak bisa memberikan gambaran umum kondisi di tiap level auditor. Level staf lebih banyak melakukan tugas yang diberikan oleh level diatasnya seperti supervisor atau manajer, sehingga untuk pengambilan keputusankeputusan terkait perilaku tuna fungsi masih sangat kecil kemungkinannya.

\section{Keterbatasan}

Keterbatasan dari penelitian ini adalah demografi responden yang ternyata sebagian besar berada di level staf, dengan demikian tidak dapat diperoleh gambaran kondisi secara menyeluruh dari semua level auditor. Hal ini mengingat bahwa level staf, terutama staf junior dalam pelaksanaan tugas auditnya tidak dapat memutuskan sesuatu yang sifatnya berkaitan dengan penerimaan perilaku tuna fungsi, sedangkan pemilik kewenangan untuk menerima atau menolak perilaku tuna fungsi auditor adalah level supervisor, manajer dan partner.

\section{Saran}

Penelitian berikutnya diharapkan untuk lebih memperluas responden baik dari sisi level jabatan pekerjaan maupun lingkup wilayah regional. Sehingga dimungkinkan responden yang lebih variatif dan lebih menggambarkan kondisi umum di masing-masing level jabatan auditor. Metode pengambilan sampel juga bisa dilakukan dengan menggunakan metode survei. Selain itu, juga dimungkinkan teknik wawancara penelitian-penelitian berikutnya untuk lebih memperdalam hasil penelitian.

\section{DAFTAR PUSTAKA}

Ajzen, Icek. 1991. "The theory of planned behavior: organizational behavior and human decision processes." Organizational Behavior and Human Decision Processes 50 (2): 179-211. https://doi.org/10.1016/0749-5978(91)90020-T.

Ardiansah, Muhammad Noor. 2003. "Pengaruh gender dan locus of control terhadap kepuasan kerja, komitmen organisasional, dan keinginan berpindah kerja auditor."

Arens, Alvin A., dan Loebbecke K James. 2006. Auditing and assurance services: an integrated approach. 11th ed. Australia: New Jersey: Person Education, Inc.

Bobek, Donna D., Amy M. Hageman, dan Robin R. Radtke. 2010. "The ethical environment of tax professionals: partner and non-partner perceptions and experiences." Journal of Business Ethics 92 (4): 637-54. https://doi.org/10.1007/s10551-009-0178-x. 
- 2015. "The effects of professional role, decision context, and gender on the ethical decision making of public accounting professionals." Behavioral Research in Accounting 27 (1): 55-78. https://doi.org/10.2308/bria-51090.

Brownell, Peter. 1981. "Participation in budgeting, locus of control and organizational effectiveness." The Accounting Review 56: 844-60. https://doi.org/10.1017/CBO9781107415324.004.

Buchheit, Steve, William R. Pasewark, dan Jerry R. Strawser. 2003. "No need to compromise: evidence of public accounting's changing culture regarding budgetary performance." Journal of Business Ethics 42: : 151-163. https://doi.org/10.1023/A:1021965119896.

Burns, Jane O, dan Pamela Kiecker. 1995. "Tax practitioner ethics: an empirical investigation of organizational consequences." Journal of the American Taxation Association 17 (2): 20-49.

Byrne, Suzanne. 2011. "Does individual locus of control matter in a JIT environment?" Journal of Applied Management Accounting Research (Winter) 9 (1): 37-58.

Cahyaningrum, Christina Dwi, dan Intiyas Utami. 2015. "Do obedience pressure and task complexity affect audit decision?" Jurnal Akuntansi dan Keuangan Indonesia 12 (1): 92-104.

Cascio, Wayne F. 2006. Applied psychology in personnel management. Edisi Keti. New Jersey: Prentice Hall.

Chen, Ching Fu. 2006. "Job satisfaction, organizational commitment, and flight attendants' turnover intentions: A note." Journal of Air Transport Management 12: 274-76. https://doi.org/10.1016/j.jairtraman.2006.05.001.

Cummings, Thomas G., dan Christopher G. Worley. 2005. Organization development and change. Australia: Mason, Ohio : Thomson South-Western.

Dessler, Gary. 2005. Human resource management. Edisi Kese. United States of America: New Jersey: Prentice Hall.

Donnelly, David P, Jeffrey J Quirin, dan David O’Bryan. 2003. “Auditor acceptance of dysfunctional audit behavior: an explanatory model using auditors personal characteristics." Behavioral Research in Accounting 15 (1): 87-107. https://doi.org/http://aaapubs.org/loi/bria.

Ford, Rc, dan Wd Richardson. 1994. "Ethical decision making: a review of the empirical literature." Journal of Business Ethics 13 (3): 205-21. https://doi.org/10.1007/BF02074820.

Gable, Myron, dan Frank Dangello. 1994. "Locus of control, machiavellianism, and managerial job performance." Journal of Psychology 128 (5): 599-608. 
https://doi.org/10.1080/00223980.1994.9914917.

Gabris, Gerald T., dan Douglas M. Ihrke. 2000. "Improving employee acceptance toward performance appraisal and merit pay systems: the role of leadership credibility." Review of Public Personnel Administration 20 (1): 41-53. https://doi.org/10.1177/0734371X0002000104.

Gibson, T., V. Jhonson, dan L. Mc.Land. 1995. Organisasi, perilaku, struktur, proses. Edisi Kedu. Jakarta: Erlangga.

Grote, Dick. 2002. The performance appraisal question and answer book a survival guide for managers. Broadway, New York: AMACOM.

Hair, Joseph F., Ronald L. Tatham, Rolph E. Anderson, dan William Black. 1998. Multivariate data analysis. Edisi keli. New Jersey: Prentice Hall. https://doi.org/10.1016/j.ijpharm.2011.02.019.

Harini, Dwi, Agus Wahyudin, dan Indah Anisykurlillah. 2010. “Analisis penerimaan auditor atas dysfunctional audit behavior: sebuah pendekatan karakteristik personal auditor." Proceeding Simposium Nasional Akuntansi XIII Purwokerto 12.

Hasibuan, H. Malayu S.P. 2005. Manajemen sumber daya manusia. Jakarta: Bumi Aksara.

Hwang, Nen Chen Richard, dan C. Janie Chang. 2010. "Litigation environment and auditors' decisions to accept clients' aggressive reporting." Journal of Accounting and Public Policy 29: 281-95. https://doi.org/10.1016/j.jaccpubpol.2010.02.002.

Hyatt, Troy A., dan Douglas F. Prawitt. 2001. "Does congruence between audit structure and auditors' locus of control affect job performance?" The $\begin{array}{llll}\text { Accounting } & \text { Review } & 76 & \text { (2): }\end{array}$ https://doi.org/10.2308/accr.2001.76.2.263.

Irawati, Yuke, dan Petronila Mukhlasin Thio Anastasia. 2005. "Hubungan karakteristik personal auditor terhadap tingkat penerimaan penyimpangan perilaku dalam audit.” In Simposium Nasional Akuntansi XVI.

Januari, Cindi Ismi, Hamidah Nayati Utami, dan Ika Ruhana. 2015. "Pengaruh penilaian kinerja terhadap kepuasan kerja dan prestasi kerja (studi pada karyawan pt. telekomunikasi Indonesia, tbk wilayah Malang)." Jurnal Administrasi Bisnis (JAB) 24 (2): 1-8.

Jones, Gwen E., dan Michael J. Kavanagh. 1996. “An experimental examination of the effects of individual and situational factors on unethical behavioral intentions in the workplace." Journal of Business Ethics 15 (5): 511-23. https://doi.org/10.1007/BF00381927. 
Kalbers, Lawrence P., dan William J. Cenker. 2007. "Organizational commitment and auditors in public accounting." Managerial Auditing Journal 22 (4): 35475. https://doi.org/10.1108/02686900710741928.

Kelley, Tim, dan Loren Margheim. 1990. "The impact of time-budget pressure, personality, and leadership variables on dysfunctional auditor behavior." Auditing: A Journal of Practice \& Theory 9: 21-42.

Kreitner, Robert, dan Angelo Kinicki. 2001. Organizational behavior. Edisi Keli. Boston: Irwin McGraw Hill.

Lord, Alan T., dan F. Todd DeZoort. 2001. "The impact of commitment and moral reasoning on auditors' responses to social influence pressure." Journal Accounting, Organizations and Society $26 \quad$ (3): 215-35. https://doi.org/10.1016/S0361-3682(00)00022-2.

Luthans, Fred, Carolyn M. Youssef, dan Bruce J. Avolio. 2011. Psychological capital: developing the human competitive advantage. New York: Oxford University Press Inc. https://doi.org/10.1093/acprof:oso/9780195187526.001.0001.

Malone, Charles F., dan Robin W. Roberts. 1996. "Factors associated with the incidence of reduced audit quality behaviors." Auditing: A Journal of Practice and Theory 15 (2): 49-64.

Marshall, Rex L., Robert W. Armstrong, dan Malcolm Smith. 1998. "The ethical environment of tax practitioners: western Australian evidence." Journal of Business Ethics 17 (12): 1265-79.

Maryanti, Puji. 2005. "Analisis penerimaan auditor atas dysfunctional audit behavior: pendekatan karakteristik personal auditor." Jurnal Manajemen Akuntansi dan Sistem Informasi 5 (2): 213-26.

Mathis, Robert L., dan John Jackson. 2006. Human resources development (track MBA series/terjemahan). Jakarta: Prestasi Pustaka.

Maulina, Mutia, Ratna Anggraini, dan Choirul Anwar. 2010. "Pengaruh tekanan waktu dan tindakan supervisi terhadap penghentian prematur atas prosedur." In Simposium Nasional Akuntansi XIII Purwokerto 2010.

McEvoy, Glenn M., dan Wayne F. Cascio. 1987. "Do good performers leave? A meta-analysis of the between performance and turnover." Academy of Management Journal 30: 744-62. https://doi.org/10.2307/256158.

Millmore, M., D. M. Biggs, dan L. Morse. 2007. "Gender differences within 360degree managerial performance appraisals." Women in Management Review 22 (7): 536-51.

Mondy, R.W., dan R. M. Noe. 2005. Human resource management. Edisi kese. New 
Jersey: Prentice Hall.

Muawanah, U., dan N. Indriantoro. 2001. "Perilaku auditor dalam situasi konflik audit: Peran locus of control, komitmen profesi dan kesadaran etis." Jurnal Riset Akuntansi Indonesia 4 (2): 133-50.

Nouri, H., dan R. J. Parker. 1998. "The relationship between budget participation and job performance: The roles of budget adequacy and organizational commitment." Journal Accounting, Organizations and Society 23: 467-83. https://doi.org/10.1016/S0361-3682(97)00036-6.

Otley, David T., dan Bernard J. Pierce. 1996. "Auditor time budget pressure: Consequences and antecedents." Accounting, Auditing \& Accountability Journal 9 (1): 31-58. https://doi.org/10.1108/09513579610109969.

Paino, H., A. Thani, dan S. I. Zulkarnain. 2011. "Dysfunctional audit behavior: The effect of budget emphasis leadership behavior and effectiveness of audit revie.” European Journal of Social Sciences 21 (3): 436-47.

Pasewark, William R, dan Jerry R Strawser. 1996. "The determinants and outcomes associated with job insecurity in a professional accounting environment." Behavioral Research in Accounting 8: 91-110.

Pasewark, William R, dan Ralph E Viator. 2006. "Sources of work-family conflict in the accounting profession." Behavioral Research in Accounting 18 (1): 14765. https://doi.org/10.2308/bria.2006.18.1.147.

Pinsker, Robert, Robin Pennington, dan Jennifer Kahle Schafer. 2009. "The influence of roles, advocacy, and adaptation to the accounting decision environment." Behavioral Research in Accounting 21 (2): 91-111. https://doi.org/10.2308/bria.2009.21.2.91.

Rhode, H. L. 1978. Survey on the influences of selected aspects of auditors work environment on profesional performance of certified public accountants. Summarized in The Commision on Auditors Responsibilities. New York: AICPA.

Robbins, Stephen P. 2001. Organizational behavior. Edisi Kese. Prentice Hall International Inc.

Rutner, P. S, B. C. Hardgrave, dan D. H. McKnight. 2008. "Emotional dissonance and the information technology professional." MIS Quarterly 32 (3): 625-52. https://doi.org/Article.

Schuler, Randall S., dan Susan E Jackson. 1996. Manajemen sumber daya manusia. Edisi Keen. Jakarta: Erlangga.

Sitanggang, Abdonsius. 2007. "Penerimaan auditor terhadap perilaku audit disfungsional: suatu model penjelasan dengan menggunakan karakteristik 
personal auditor (studi empiris pada auditor kantor akuntan publik di DKI Jakarta)." Universitas Diponegoro Semarang.

Solar, Diana, dan Dieter Bruehl. 1971. "Machiavellianism and locus of control: two conceptions of interpersonal power." Psychological Reports 29: 1079-82.

Soobaroyen, Teerooven, dan Chelven Chengabroyan. 2006. “Auditor's perceptions of time budget pressure, premature sign offs and under-reporting of chargeable time: Evidence from a developing country." International Journal of Auditing 10 (3): 201-18. https://doi.org/10.1111/j.10991123.2006.0350.x.

Steensma, Herman, dan Ellen Visser. 2007. "Procedural justice and supervisors personal power bases: Effects on employees perceptions of performance appraisal sessions, commitment, and motivation." Journal Collective Negotiations 31 (2): 101-18.

Sweeney, Breda, Don Arnold, dan Bernard Pierce. 2010. "The impact of perceived ethical culture of the firm and demographic variables on auditors' ethical evaluation and intention to act decisions." Journal of Business Ethics 93 (4): 531-51.

Trevino, L. K. 1986. "Ethical decision making in organizations: a person-situation interactionist model." Academy of Management Review 1: 601-17. https://doi.org/10.5465/AMR.1986.4306235.

Trevino, Linda Klebe, dan Stuart A. Youngblood. 1990. "Bad apples in bad barrels: a causal analysis of ethical decision making behavior." Journal of Applied Psychology 75 (4): 378-85.

Utami, Intiyas, Yefta Andi Kus Noegroho, dan Fenny Indrawati. 2007. "Pengaruh locus of control, komitmen profesional, pengalaman audit terhadap perilaku akuntan publik dalam konflik audit dengan kesadaran etis sebagai variabel pemoderasi." Jurnal Akuntansi dan Keuangan Indonesia 4 (2): 193-210.

Yetmar, Scott A., dan Kenneth K. Eastman. 2000. "Tax practitioners' ethical sensitivity: a model and empirical examination." Journal of Business Ethics 26 (4): 271-88. https://doi.org/10.1023/A:1006294517573. 